\title{
Kenny-Caffey Syndrome
}

National Cancer Institute

\section{Source}

National Cancer Institute. Kenny-Caffey Syndrome. NCI Thesaurus. Code C130991.

A genetic condition characterized by long bone sclerosis and thickening, short stature, and head and eye anomalies. Many affected individuals have hypoparathyroidism with hypocalcemia. 